\title{
A Drosophila KCNQ Channel Essential for Early Embryonic Development
}

\author{
Hua Wen, ${ }^{\star}$ Thomas M. Weiger, ${ }^{\star}$ Tanya S. Ferguson, ${ }^{\star}$ Mohammad Shahidullah, Samae S. Scott, and Irwin B. Levitan \\ Department of Neuroscience, University of Pennsylvania School of Medicine, Philadelphia, Pennsylvania 19104
}

The mammalian voltage-dependent KCNQ channels are responsible for distinct types of native potassium currents and are associated with several human diseases. We cloned a novel Drosophila KCNQ channel (dKCNQ) based on its sequence homology to the mammalian genes. When expressed in Chinese hamster ovary cells, $\mathrm{dKCNQ}$ gives rise to a slowly activating and slowly deactivating current that activates in the subthreshold voltage range. Like the M-current produced by mammalian KCNQ channels, dKCNQ current is sensitive to the KCNQ-specific blocker linopirdine and is suppressed by activation of a muscarinic receptor. $\mathrm{KKCNQ}$ is also similar to the mammalian channels in that it binds calmodulin (CaM), and CaM binding is necessary to produce functional currents. In situ hybridization analysis demonstrates that $d K C N Q$ mRNA is present in brain cortical neurons, the cardia (proventriculus), and the nurse cells and oocytes of the ovary. We generated mutant flies with deletions in the genomic sequence of $d K C N Q$. Embryos produced by homozygous deletion females exhibit disorganized nuclei and fail to hatch, suggesting strongly that a maternal contribution of $\mathrm{dKCNQ}$ protein and/or mRNA is essential for early embryonic development.

Key words: KCNQ channels; M-current; Drosophila ion channels; embryonic development; fly mutants; maternal effect

\section{Introduction}

KCNQs are relatively new additions to the voltage-dependent potassium (Kv) channel superfamily. The functional significance of KCNQ channels is highlighted by their relevance to native currents and their association with human diseases. Five KCNQ genes have been cloned to date, all from mammals. The first member, KCNQ1, coassembles with a regulatory $\beta$-subunit, KCNE1, to produce the slow delayed rectifier current $\left(I_{\mathrm{Ks}}\right)$ in cardiomyocytes (Wang et al., 1996; Yang et al., 1997). Mutations in KCNQ1 cause prolongation of cardiac action potentials and are responsible for one form of long QT syndrome (Sanguinetti et al., 1996). KCNQ1/KCNE1 is also expressed in the cochlea, and mutations of either gene are associated with hearing loss (Neyroud et al., 1997; Schulze-Bahr et al., 1997). KCNQ2 and KCNQ3 were cloned by linkage to a form of human epilepsy (Biervert et al., 1998; Charlier et al., 1998; Schroeder et al., 1998; Singh et al., 1998). The heteromeric channel formed by these subunits is believed to be the major molecular correlate of the neuronal

\section{Received Aug. 19, 2003; revised Sept. 19, 2005; accepted Sept. 20, 2005.}

This work was supported by grants from the National Institutes of Health and the McKnight Endowment Fund for Neuroscience (I.B.L.) and from the University of Salzburg (T.M.W.). We are grateful to John Lowenstein for CaM CDNA and Neil Nathanson for M1 receptor CDNA. We thank Haoyu Zeng, David Levitan, Smitha Reddy, and Angela Jaramillo for technical advice and assistance, Karen Ho and Angela Jaramillo for critical comments on this manuscript, and other Levitan laboratory members for helpful suggestions and discussion.

*H.W., T.M.W., and T.S.F. contributed equally to this work.

Correspondence should be addressed to Dr. Irwin B. Levitan, Department of Neuroscience, University of Pennsylvania School of Medicine, 3450 Hamilton Walk, Philadelphia, PA 19104. E-mail: levitani@mail.med.upenn.edu.

H. Wen's present address: Department of Neurobiology and Behavior, State University of New York at Stony Brook, Stony Brook, NY 11794.

T. M. Weiger's present address: Department of Cell Biology, Division of Animal Physiology, University of Salzburg, Hellbrunner Strasse 34, A-5020 Salzburg, Austria.

DOI:10.1523/JNEUROSCI.3086-05.2005

Copyright $\odot 2005$ Society for Neuroscience $\quad$ 0270-6474/05/2510147-10\$15.00/0
M-current, a key regulator of neuronal excitability (Brown and Adams, 1980; Wang et al., 1998). KCNQ4 and KCNQ5 were identified by their sequence homology to other family members (Kubisch et al., 1999; Lerche et al., 2000; Schroeder et al., 2000a). KCNQ4 mutations are associated with a form of dominant deafness in humans (Kubisch et al., 1999). KCNQ5 is found in high levels in the cortex and hippocampus of the mouse, and its activity is inhibited by the M-current blockers linopirdine and XE991, suggesting that it may contribute to the M-current in some neurons (Schroeder et al., 2000a; Jensen et al., 2005).

The structure and function of major classes of Kv channels are generally conserved between mammals and invertebrates. The genetically accessible fruit fly Drosophila has served as an excellent model system for Kv channel studies. For example, several Kv channels, including the prototypical Shaker, EAG, and Slo, were first cloned from flies based on their mutant behavioral phenotypes (Kamb et al., 1987; Papazian et al., 1987; Pongs et al., 1988; Atkinson et al., 1991; Warmke et al., 1991; Adelman et al., 1992). Lesions in Shaker (Wu et al., 1983), Slo (Elkins et al., 1986; Zhong and $\mathrm{Wu}, 1991$ ), and Shab (Hegde et al., 1999) genes selectively affect distinct types of potassium currents in the larval body wall muscle of mutant flies.

Kv channels have been divided into seven families based on sequence distances (Hille, 2001), and six of them have been cloned in Drosophila. An analysis of the complete Drosophila genome has predicted a seventh Kv family, composed of a single KCNQ-related gene (Littleton and Ganetzky, 2000). We cloned the novel Drosophila KCNQ gene $d K C N Q$. When it is expressed in heterologous cells, dKCNQ forms a functional channel that resembles the mammalian KCNQ channels in several aspects. To study in vivo function, we generated several independent fly lines with deletions in the $d K C N Q$ gene locus and analyzed mutant 
phenotypes. Surprisingly, we find that maternally contributed dKCNQ protein and/or mRNA is essential for early embryonic development.

\section{Materials and Methods}

Cloning of $d K C N Q$. Database searches were performed using the BLAST (basic local alignment search tool) server (National Center for Biotechnology Information). AE003830, a genomic scaffold clone from the right arm of chromosome 2, was sequenced by the Drosophila Genome Project (Adams et al., 2000). Genomic sequences that show significant homologies with mouse KCNQ2 ( $m K C N Q 2)$ on the protein level lie in the chromosomal region 46F3 (23506-31391 of AE003830, Drosophila genome annotation, release 3.0). Primers were designed according to the two candidate protein sequences in that region (Flybase accession number FBgn0033494, KCNQ-PA and KCNQ-PB; GenBank accession numbers NM_176120 and NM_176119) and used to amplify $d K C N Q$ from an embryonic cDNA library (Drosophila Quick-clone cDNA; Clontech, Palo Alto, CA), Drosophila melanogaster RE26469 full insert cDNA [GenBank accession numbers BT001588, an embryonic cDNA expressed sequence tag (EST), kindly generated by Piero Carninci at RIKEN (Saitama, Japan) with mRNA from Ling Hong, donated through the Berkeley Drosophila Genome Project (University of California at Berkeley, Berkeley, CA)], and adult Canton S and $y w$ fly cDNA. Adult fly cDNA was created by extracting mRNA from 25 flies using Ultraspec RNA Isolation System (Biotex, Houston, TX) and was reverse transcribed using Superscript First-Strand Synthesis System for reverse transcription (RT)-PCR (Invitrogen, Carlsbad, CA). The primer pair was as follows: coding primer, 5' -GTTGTGGAATGAGATCAGAATGGAT-3'; and noncoding primer, 5' -CGGTAATGTAAGATTTGCTGCT-3'.

The PCR product was cloned into the pcDNA3.1-Topo-V5-His mammalian expression vector with the $\mathrm{V} 5$ tag at the $\mathrm{C}$ terminus (Invitrogen, San Diego, CA). The sequence of $d K C N Q$ has been deposited into GenBank (accession numbers AY823300 for Canton S and AY823301 for $y$ w). Although the PCR products were also cloned into PCMV-HA and pCMV-Myc (Clontech), we found that these $\mathrm{N}$-terminal tags abolish the functional activity of the channel.

Electrophysiology constructs and reagents. dKCNQ cDNA was cloned into pIRES2-EGFP, a bicistronic vector that allows coexpression of the channel and the enhanced green fluorescent protein (EGFP) in the same cell (Clontech). dKCNQ (R326E) in pIRES2-EGFP was generated by site-directed mutagenesis using Quik-Change system (Stratagene, La Jolla, CA) according to the instructions of the manufacturer, and the mutation was confirmed by sequencing through the entire coding region. CaM cDNA (the kind gift from Dr. John Lowenstein, Brandeis University, Waltham, MA) was subcloned into a modified version of the mammalian expression vector pcDNA3.1 to give it a HA-epitope tag at the N terminus. cDNA for mouse $M_{1}$ receptor was kindly provided by Neil Nathanson (University of Washington, Seattle, WA) and was subcloned into the EcoRI and BamHI sites of pIRES2-EGFP.

Oxotremorine M (Oxo M) and linopirdine (DuP 996) were from Research Biochemicals (Natick, MA). All other chemicals were obtained from Sigma (St. Louis, MO).

Antibody preparation, coimmunoprecipitation, and Western blotting. Anti-dKCNQ rabbit antiserum J-67 was generated against amino acids 691-741 in the C terminus of dKCNQ, expressed as a glutathione- $S$ transferase fusion protein. The antibody was then affinity purified against a maltose-binding protein fusion protein containing the same dKCNQ fragment.

Coimmunoprecipitation and Western blotting were done as described previously (Wang et al., 1999). In brief, tsA201 cells were maintained in MEM supplemented with $10 \%$ fetal bovine serum (FBS). Forty-eight hours after transfection with a calcium phosphate protocol, cells were lysed in a buffer containing 1\% CHAPS (3-[(3-cholamidopropyl) dimethylammonio]-1-propanesulfonate), $20 \mathrm{~mm}$ Tris- $\mathrm{HCl}, \mathrm{pH}$ 7.5, 10 mм EDTA, $120 \mathrm{~mm} \mathrm{NaCl}, 50 \mathrm{~mm} \mathrm{KCl,} 50 \mathrm{~mm} \mathrm{NaF}, 2 \mathrm{~mm}$ DTT, and protease inhibitors ( $1 \mathrm{~mm}$ PMSF and $1 \mu \mathrm{g} / \mathrm{ml}$ each aprotonin, leupeptin, and pepstatin A). Cleared lysates were incubated overnight at $4^{\circ} \mathrm{C}$ with $\mathrm{J}-67$, and the immunocomplexes were precipitated with protein $\mathrm{A} / \mathrm{G}$ agarose beads (Santa Cruz Biotechnology, Santa Cruz, CA).
Proteins in the cell lysates or immunoprecipitates were separated on polyacrylamide gels and transferred to nitrocellulose membranes. The blots were blocked with $5 \%$ nonfat milk in TBST ( $10 \mathrm{~mm}$ Tris- $\mathrm{HCl}, \mathrm{pH}$ $7.5,150 \mathrm{~mm} \mathrm{NaCl}$, and $0.1 \%$ Tween 20 ) and then incubated with antidKCNQ J-67 or anti-CaM (Upstate Biotechnology, Lake Placid, NY) in blocking buffer at $4^{\circ} \mathrm{C}$ overnight. After three washes with TBST, blots were incubated with $\mathrm{HRP}$-conjugated anti-rabbit or anti-mouse IgG (Amersham Biosciences, Arlington Heights, IL) for $1 \mathrm{~h}$ at room temperature. Proteins were visualized with an enhanced chemiluminescence detection system (Amersham Biosciences).

Electrophysiology. Chinese hamster ovary $(\mathrm{CHO})$ cells were maintained in Ham's F-12 medium containing 10\% FBS and 1\% penicillin/ streptomycin. They were transfected using Lipofectamine 2000 (Invitrogen, Gaithersburg, MD) according to the instructions of the manufacturer. Cells were either transfected with pIRES2-EGFP $d K C N Q$ constructs or cotransfected with V5-tagged $d K C N Q$ channel construct and EGFP. Currents produced by the C-terminal-tagged channel are indistinguishable from those produced by the untagged version.

Twenty-four to $48 \mathrm{~h}$ after transfection, dKCNQ currents were recorded in the whole-cell configuration using an Axo-patch 200A amplifier (Molecular Devices, Union City, CA). Pipette electrodes were pulled from borosilicate glass and had resistances of 2-3 $\mathrm{M} \Omega$. The bath solution consisted of the following (in $\mathrm{mm}$ ): $145 \mathrm{NaCl}, 5 \mathrm{KCl}, 2 \mathrm{MgCl}_{2}, 2 \mathrm{CaCl}_{2}$, and 10 HEPES, $\mathrm{pH}$ 7.2. The electrode solution consisted of the following (in mM): $140 \mathrm{KCl}, 0.5 \mathrm{MgCl}_{2}, 2 \mathrm{CaCl}_{2}, 5 \mathrm{EGTA}$, and $10 \mathrm{HEPES}$, pH 7.2. This gives an internal solution containing $100 \mathrm{~nm}$ free $\mathrm{Ca}^{2+}$, as calculated with Equal software (Biosoft, Cambridge, UK). Two millimolar ATP was included in the electrode solution for some experiments, with similar results. Data were acquired and analyzed with pClamp 8 software (Axon Instruments). All results are shown as mean \pm SEM, and statistical significance was assessed by Student's $t$ test (Origin software; Microcal Software, Northampton, MA).

Fly stocks. Flies were raised on standard molasses food at $25^{\circ} \mathrm{C}$. $E P(2) 2074$ insertion line ( w; EP2074/CyO; +) was from the Berkeley Drosophila Genome Project collection of EP lines from the controlled misexpression project (Rorth, 1996; Rorth et al., 1998). Wild-type Canton $\mathrm{S}$ flies, the transposase line ( $w ; w g / C y O ; \Delta 2-3 D r / T M 6)$, and other fly lines were generously provided by Leslie Griffith (Brandeis University, Waltham, MA)

Generation and characterization of $d K C N Q$-deletion lines. The precise insertion site of the EP(2)2074 element within the $d K C N Q$ gene was confirmed by inverse PCR and direct sequencing of genomic DNA flanking the insertion site. Precise and imprecise excision lines were generated by mobilizing the P-element using $\Delta 2-3$ as the source of transposase (Robertson et al., 1988). The $\Delta 2-3$ line has the Drop marker gene on the third chromosome, so the introduction into and removal from the genome of the transposase can be followed easily. The jumps were generated as follows. First, w; EP(2)2074/CyO; + males were crossed with $w$; $w g / C y O ; \Delta 2-3$ Dr/TM6 females. Second, F1 male progenies with genotype $w ; E P(2) 2074 / C y O ; \Delta 2-3 D r /+$ were selected and crossed with $w$; $\mathrm{Xa} / \mathrm{CyO}$; $\mathrm{Xa} /+$ females. $E P(2) 2074 / C y O$ balancer heterozygotes were chosen rather than $E P / w g$ flies, because imprecise excision is favored by the absence of a homologous wild-type chromosome at the insertion site (O'Kane, 1998). Third, excision of the P-element from the genome $\left(\mathrm{EP}_{\text {loss }}\right)$ was judged by the loss of eye color carried by the $w^{+m C}$ minigene on the P-element. Single white-eyed F2 males with genotype $w$; $E P_{\text {loss }}$ l $\mathrm{CyO}$; + were crossed individually with $w ; \mathrm{Xa} / \mathrm{CyO} ; \mathrm{Xa} /+$ females. Last, each excision line was maintained as a balanced stock by sibling matings of heterozygous $w ; E P_{\text {loss }} / C y O F 3$ flies. Homozygous excision flies in the $\mathrm{F} 4$ generation were then used in the analysis for imprecise excisions.

P-element mutagenesis generated 103 excision lines, 19 of which were homozygous lethal. The remaining viable excision lines were analyzed for deletions using a PCR strategy. Genomic DNA was prepared from homozygous flies of each excision line and used as template for the PCR screening. The primer pair L80 and R50 was used in the first round of PCR reactions. These primers are located $\sim 440 \mathrm{bp}$ upstream and $200 \mathrm{bp}$ downstream of the original P-element insertion site, respectively, and amplify a $646 \mathrm{bp} d K C N Q$ genomic DNA fragment from the wild-type and the precise excision lines. They amplify a smaller fragment if a dele- 
tion occurred in the region between the primers. Excision lines in which this primer pair did not produce a PCR product presumably contain larger deletions that remove at least one of the primer sites, so they were put to the next round of PCR testing, with another pair of primers farther away from the original insertion site. The process was repeated until a genomic fragment was PCR amplified from each deletion line. The PCR products were then sequenced to determine the deletion breakpoints on the $d K C N Q$ genomic DNA. Primer pair L80 and R026 was used to sequence the deletion line $d K C N Q^{18 B}$, L50 and R026 for line $d K C N Q^{35 B}$, $\mathrm{L} 3274$ and R50 for line $d K C N Q^{42 B}, \mathrm{~L} 50$ and R80 for line $d K C N Q^{53 B}$, and L3274 and R3847 for line $d K C N Q^{64 B}$, respectively. The sequences of these primers are as follows: L50, 5'-GTGAGGTGCTAAAAAGTCGAGG-3'; L80, 5'-AGACGGATAGAAAGACAGTCGG-3'; L3274, 5' AGGACCTTGTAGACTTACCGTCTG-3'; R50, 5'-ATAGAAGCGCAGCCACAGT-3'; R80, 5'-ATCAAGGAGTACGAAGAGGACG-3'; R026, 5'-CTCCCGCTTCCCACATACAATTAG-3'; and R3847, 5'-CGAATGTCACTCCTAGGAAAGCCGCTGAACTAC-3'.

In four of the five deletion lines we recovered, there are stretches of short sequences left between the deletion breakpoints. They are 1-33 bp in length and probably are derived from the original P-element insert. We also observed excisions that occurred internally within the $\mathrm{P}$-element, leaving the remaining $\mathrm{P}$-element sequences at the insertion site but with normal flanking $d K C N Q$ genomic sequences. These lines and homozygous lethal excision lines (that produced no straight-winged flies in F4) were not analyzed.

Embryo collection. Male and female flies were placed at $25^{\circ} \mathrm{C}$ with a standard light/dark cycle for $18-24 \mathrm{~h}$ in a cage on a plate (5\% sucrose, $1.8 \%$ agar, and $0.5 \%$ of a 9:1 ratio of propionic acid/phosphoric acid). Fresh instant yeast mixed with water $(0.5-1 \mathrm{ml})$ was placed at the center of each plate as a food source. Before collection of embryos, the cages were transferred to new plates with yeast, and embryos were collected every hour under a dissecting microscope.

Embryo 4',6 diamidino-2-phenylindole labeling. Embryos were collected from either precise excision females $\left(d K C N Q^{24 B}\right)$ or homozygous deletion females $\left(d K C N Q^{53 B}\right)$. They were dechorionated with $50 \%$ bleach and fixed with $4 \%$ paraformaldehyde/heptane. After the vitelline membrane was removed with methanol, embryos were stained with 4',6 diamidino-2-phenylindole (DAPI) in mounting medium (Vector Laboratories, Burlingame, CA) and examined under a Leica (Nussloch, Germany) DMIRE2 fluorescence microscope.

Whole fly in situ hybridization. Digoxiginen (DIG)-labeled probes were synthesized from $d K C N Q$ cDNA using the following primers: $5^{\prime}$ AGACAGGGATCCATCACAACCGTGTACATAG-3' and 5'-GAAGCTGGATCCCGCCCGTGAAGCTGGCGGAC-3', which amplifies a sequence within the region of the $d K C N Q$ gene that is absent in the deletion fly lines. Probes were labeled using a DIG RNA labeling kit (Roche, Indianapolis, IN) and stored in hybridization buffer until use. Probe concentration was determined by dot blot before use.

Male and female adult precise excision and homozygous deletion flies were killed, embedded in Tissue-Tek (Sakura Finetek USA, Torrance, CA), frozen, and cut at $12 \mathrm{~mm}$ at $-20^{\circ} \mathrm{C}$. Sections were mounted on Superfrost plus slides (Fisher Scientific, Pittsburgh, PA) and air dried and then were labeled using the method found on L. B. Voshall's website (www.rockefeller.edu/labheads/vosshall/protocols.php, access date July $21,2005)$. Briefly, sections were fixed in $4 \%$ paraformaldehyde in PBS, washed three times for three min in PBST (PBS plus $0.1 \%$ Triton X-100), and acetylated in acetylation solution $(9.5 \mathrm{~g}$ of triethanolamine $\mathrm{HCl}, 1.12$ $\mathrm{ml}$ of $10 \mathrm{~N} \mathrm{NaOH}$, and $1.25 \mathrm{ml}$ of acetic anhydride in $500 \mathrm{ml}$ of $\mathrm{H}_{2} \mathrm{O}$ ) for $10 \mathrm{~min}$ at room temperature. After acetylation, sections were rinsed three times for $5 \mathrm{~min}$ in PBST and prehybridized in hybridization buffer at $55^{\circ} \mathrm{C}$ for $1 \mathrm{~h}$. Slides were hybridized overnight at $55^{\circ} \mathrm{C}$ in a humidified chamber, rinsed three times for $20 \mathrm{~min}$ in $0.2 \times$ saline sodium citrate at $55^{\circ} \mathrm{C}$, and final rinsed in PBST for $10 \mathrm{~min}$. Slides were blocked in $10 \%$ normal goat serum in PBST for $1 \mathrm{~h}$ at room temperature, and then 1:1000 anti-DIG antibody (Roche) diluted in 10\% normal goat serum in PBST was added overnight at $4^{\circ} \mathrm{C}$. The next day, slides were rinsed three times for $30 \mathrm{~min}$ in PBST, equilibrated in TBST (Tris-buffered saline, $\mathrm{pH}$ 9.5, with $0.1 \%$ Tween 20 ) plus $50 \mathrm{~mm} \mathrm{MgCl}_{2}$ for $10 \mathrm{~min}$ at room temperature, and then developed with nitroblue-tetrazolium-chloride/5-bromo-4chlor-indolyl-phosphate stock solution (Roche) with $1 \mathrm{~mm}$ levamisole.

Ovary in situ hybridization. Whole ovaries were removed from 2- to 5 -d-old flies in ice-cold PBS. Ovaries were fixed in heptane fix (4\% paraformaldehyde in PBS, $15 \mathrm{~mm}$ HEPES, $1 \mathrm{~mm} \mathrm{MgSO}_{4}, 2 \mathrm{~mm}$ EGTA, and $50 \% \mathrm{v} / \mathrm{v}$ heptane) for $20 \mathrm{~min}$ at room temperature, rinsed two times in methanol and two times in ethanol, and stored in ethanol until use. On the day of probe addition, ovaries were rehydrated, refixed in $4 \%$ paraformaldehyde in PBST with the addition of $50 \% \mathrm{v} / \mathrm{v}$ DMSO, and rinsed five times for $1 \mathrm{~min}$ in PBST. After a brief $30 \mathrm{~s}$ digestion in Proteinase $\mathrm{K}$ $(10 \mathrm{mg} / \mathrm{ml})$, ovaries were rinsed in a $10 \mathrm{mg} / \mathrm{ml}$ glycine solution and refixed in 4\% paraformaldehyde in PBST for $20 \mathrm{~min}$ at room temperature. Ovaries were rinsed five times for $1 \mathrm{~min}$ in PBST and prehybridized in hybridization buffer at $55^{\circ} \mathrm{C}$. In situ hybridization was then performed as described for whole fly in situ.

Embryo RT-PCR. $d K N C Q^{24 B}$ precise excision and $d K C N Q^{53 B}$ deletion flies were crossed as follows: $24 B$ female $\times 24 B$ male, $53 B$ female $\times 53 B$ male. Each cross, along with Canton $S$ and yellow white controls, was placed in cages on plates for collection. More than 100 embryos were collected and stored at $-80^{\circ} \mathrm{C}$ until use. mRNA was extracted using RNAqueous-Micro RNA isolation kit (Ambion, Austin, TX) and reverse transcribed using Superscript First-Strand Synthesis System for RT-PCR (Invitrogen, Carlsbad, CA). Primers, designed within the deleted region of the $d K C N Q$ gene, were 5'-GATCGGCGGGGCGGCACCTG-3' and $5^{\prime}$-CGGCGTCTGGATCGTCTGGCTCTT- ${ }^{\prime}$. The expected band size is $545 \mathrm{bp}$. The band was cut out and sequenced to ensure that it was the correct product. Embryo collection and RT-PCR were repeated five times.

\section{Results}

\section{Cloning of a novel KCNQ gene from Drosophila}

We used the protein sequence of mouse KCNQ2 to search the Drosophila genome and identified a genomic sequence in $46 \mathrm{~F} 3$ on the right arm of chromosome 2 that shares significant homology with the mammalian channel on the protein level. We used PCR to amplify and clone cDNA from an embryonic cDNA library, an embryonic EST cDNA, and adult cDNA to test the existence of the two predicted Drosophila KCNQ transcript sequences. The difference between the two predicted transcripts, PA (long) and $\mathrm{PB}$ (short), is the presence or absence of two exons found in the C-terminal region past the last predicted transmembrane domain. In both embryo and adult, we were only able to find the PB, or shorter version of the transcript, which we now refer to as dKCNQ.

dKCNQ cDNA encodes a novel protein of 809 amino acids (supplemental Fig. 1, available at www.jneurosci.org as supplemental material). Alignment of $d K C N Q$ cDNA and genomic sequences indicates that the $d K C N Q$ coding region is composed of 17 exons. Similar to mammalian KCNQ channels, dKCNQ protein has six putative transmembrane domains, followed by a long cytoplasmic C-terminal domain. The Drosophila protein is $36 \%$ identical and $48 \%$ similar to the mKCNQ2 channel (supplemental Fig. 1, available at www.jneurosci.org as supplemental material). The S1 through S6 transmembrane domains are highly conserved, with $63 \%$ identical and $77 \%$ similar amino acid residues. Hence, dKCNQ has all the elements for a voltage-dependent potassium channel, including the string of positive charges in S4 that is believed to be the voltage sensor and the GYGD signature sequence in the pore region that constitutes the potassium selectivity filter when four subunits come together to form a functional channel. Conversely, the conservation in the C-terminal domain is low (24\% identity and 33\% similarity). Interestingly, there is far greater homology in two domains that correspond to the two CaM binding sites we identified in mouse KCNQ2 (supplemental Fig. 1, available at www.jneurosci.org as supplemental 

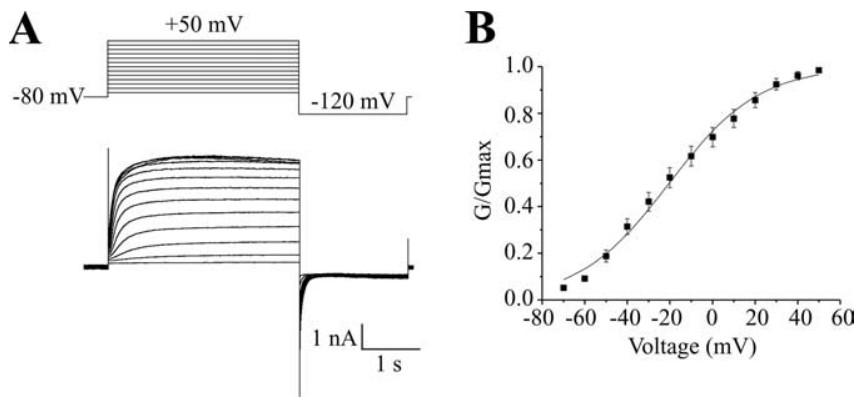

Figure 1. Voltage-dependent activation of the dKCNQ channel. $\boldsymbol{A}$, Representative recording traces of dKCNQ current (bottom traces). CHO cells were transfected with CDNA for $d K C N Q$. Cells were held at $-80 \mathrm{mV}$, and steps in increments of $10 \mathrm{mV}$ were applied up to $+50 \mathrm{mV}$ (top traces). After $4 \mathrm{~s}$, cells were stepped to $-120 \mathrm{mV}$, and tail currents were measured. $\boldsymbol{B}$, Voltagedependent activation curve of dKCNQ. G/G $G_{\max }$ was calculated from tail currents at $-120 \mathrm{mV}$. Data were fit to a Boltzmann equation: $G / G_{\max }=1 /\left(1+\exp \left(\left(V_{0.5}-V\right) / k\right)\right)$, where $V_{0.5}$ is the half-maximal activation voltage, and $k$ is inversely proportional to the slope. $V_{0.5}=-20.3 \mathrm{mV}$; slope factor $=21.2 \mathrm{mV} / e$-fold $; n=7$.

material) (Wen and Levitan, 2002). dKCNQ is also similar to the mouse KCNQ2 channel in that it contains no N-linked glycosylation site within its extracellular regions, but multiple (10) potential protein kinase $\mathrm{C}$ substrate sites in its $\mathrm{C}$-terminal domain.

Five KCNQ genes have been cloned in mammals, and three have been characterized for Caenorhabditis elegans (Wei et al., 1996, 2005), but homology searches of the Drosophila genomic sequence database did not reveal any additional KCNQ-related genes. Therefore, it appears that dKCNQ is the only KCNQ homolog in Drosophila.

\section{dKCNQ forms a functional KCNQ-like channel in CHO cells}

We tested the possible function of dKCNQ as a potassium channel by whole-cell recording from $\mathrm{CHO}$ cells transfected with $d K C N Q$ cDNA. CHO cells have been shown to lack endogenous potassium current (Yu and Kerchner, 1998), and we did not observe any current from untransfected cells under our recording conditions. Outward currents were detected 1-2 d after transfection of $d K C N Q$ (Fig. 1 $A$ ). These currents show several features that are shared by both the native $\mathrm{M}$-current and recombinant KCNQ2/3 channels recorded under the same conditions. First, $\mathrm{dKCNQ}$ currents are activated at subthreshold membrane potentials; the voltage activation curve (Fig. $1 B$ ) reaches halfmaximum activation at approximately $-20 \mathrm{mV}$. Compared with KCNQ2/3 channels, dKCNQ appears to open at more hyperpolarized membrane potentials, but its voltage dependence is weaker. The depolarization required for an $e$-fold increase in conductance is $21 \mathrm{mV}$ for dKCNQ (Fig. $1 \mathrm{~B}$ ) compared with 12 $\mathrm{mV}$ for KCNQ2/3 (Selyanko et al., 2000; Wen and Levitan, 2002). Second, dKCNQ currents have slow activation and deactivation kinetics. The activation can be described by a sum of two exponentials, with time constants of $1748 \pm 362$ and $151 \pm 16 \mathrm{~ms}(n=$ 5 ), at $0 \mathrm{mV}$. The deactivation can also be fitted to a second-order exponential function. When recorded at $-120 \mathrm{mV}$ after a depolarizing step to $0 \mathrm{mV}$ for $1 \mathrm{~s}$, the slow component of deactivation has a time constant of $137 \pm 13 \mathrm{~ms}$ and the fast component of $105 \pm 75 \mathrm{~ms}(n=5)$.

\section{dKCNQ is inhibited by a M-current-specific blocker}

Linopirdine and its analog XE-991 have been shown to inhibit both native $\mathrm{M}$-current and cloned mammalian KCNQ channels in the micromolar to submicromolar concentration range (Costa and Brown, 1997; Lamas et al., 1997; Wang et al., 1998; Kubisch et al., 1999; Lerche et al., 2000; Schroeder et al., 2000a). Evidence supports the notion that linopirdine acts extracellularly, probably by binding directly to the channel (Costa and Brown, 1997). Considering the sequence similarity between the mammalian channels and the fly channel in the N-terminal region, including the putative transmembrane domains and extracellular loops, we tested whether dKCNQ current is also blocked by linopirdine. When $100 \mathrm{~mm}$ linopirdine is applied to the bath solution, $90 \%$ of the whole-cell dKCNQ current is blocked (Fig. 2A). The doseresponse curve shows that linopirdine inhibits the fly KCNQ channel with an $\mathrm{IC}_{50}$ value of $10.8 \mathrm{~mm}$ (Fig. $2 \mathrm{~B}$ ), similar to that for the mammalian channels. The Hill slope of the curve is 1.1, indicating a one-to-one stoichiometry of the inhibitor with the channel.

\section{dKCNQ is inhibited by muscarinic receptor activation}

Activation of an array of G-protein-coupled receptors modulates the native M-current. M-current was given its name because it was first shown to be inhibited by agonists for the $M_{1}$ muscarinic receptor (Brown and Adams, 1980). Muscarinic suppression of the cloned KCNQ1-KCNQ5 channels has been reconstituted in heterologous cells coexpressing the receptor and appears to use a similar intracellular signaling mechanism as that for the native current (Schroeder et al., 2000b; Selyanko et al., 2000; Shapiro et al., 2000). Recent studies support the hypothesis that depletion of the essential membrane lipid phosphatidylinositol-4,5bisphosphate during receptor activation contributes to the suppression of channel activity (Suh and Hille, 2002; Zhang et al., 2003).

We coexpressed the dKCNQ channel and an $M_{1}$ receptor in $\mathrm{CHO}$ cells. Whole-cell currents were measured before and 1-2 min after stimulation of the receptor with $10 \mathrm{~mm}$ Oxo M (Fig. $2 C)$. In cells expressing dKCNQ alone, $100 \pm 5.2 \%(n=11)$ of the current remains 1-2 min after Oxo $\mathrm{M}$ application, whereas currents are reduced to $28 \pm 5 \%(n=11)$ of the starting level by Oxo $\mathrm{M}$ in cells coexpressing the $\mathrm{M}_{1}$ receptor $(p<0.05$, Student's $t$ test). Thus, dKCNQ shares this defining feature of M-current, modulation by muscarinic receptor activation.

\section{Calmodulin binding is necessary for dKCNQ activity}

We and others have shown using biochemical assays that the highly conserved $\mathrm{Ca}^{2+}$-binding protein calmodulin binds to mammalian KCNQ channels constitutively (Wen and Levitan, 2002; Yus-Najera et al., 2002; Gamper and Shapiro, 2003). Our mutagenesis and competition experiments provided evidence that CaM binding is essential for the functional expression of M-like current (Wen and Levitan, 2002). We tested whether this also applies to the Drosophila channel.

The two CaM-binding motifs in the proximal portion of the C-terminal domain of the mammalian channels are also conserved in the fly channel (supplemental Fig. 1, site 1 and site 2, available at www.jneurosci.org as supplemental material). A dKCNQ fragment containing the two CaM-binding sites and the connecting sequences between them (amino acids 300-463) interacts with CaM when tested by the yeast two-hybrid interaction assay (data not shown). In addition, both endogenous (Fig. $3 A$, lane 3) and overexpressed (Fig. 3A, lane 2) CaM coimmunoprecipitate with the full-length $\mathrm{dKCNQ}$ channel in heterologous cells. We have shown previously that changing a conserved arginine residue in CaM-binding site 1 of KCNQ2 to a glutamate abolishes CaM binding. This mutant KCNQ2 channel does not produce measurable current when coexpressed with KCNQ3, although it is targeted to the cell surface and heteromerizes with 


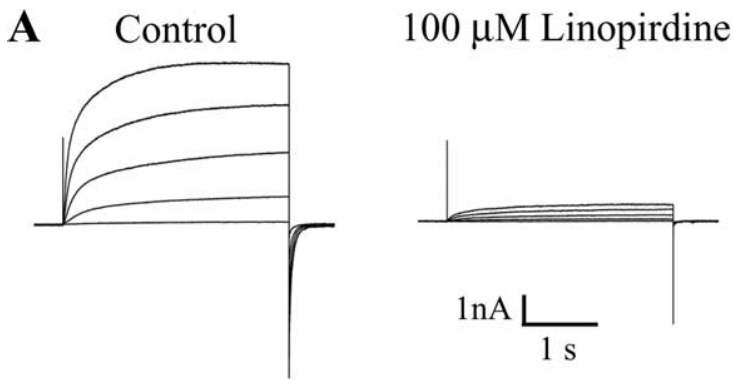

B
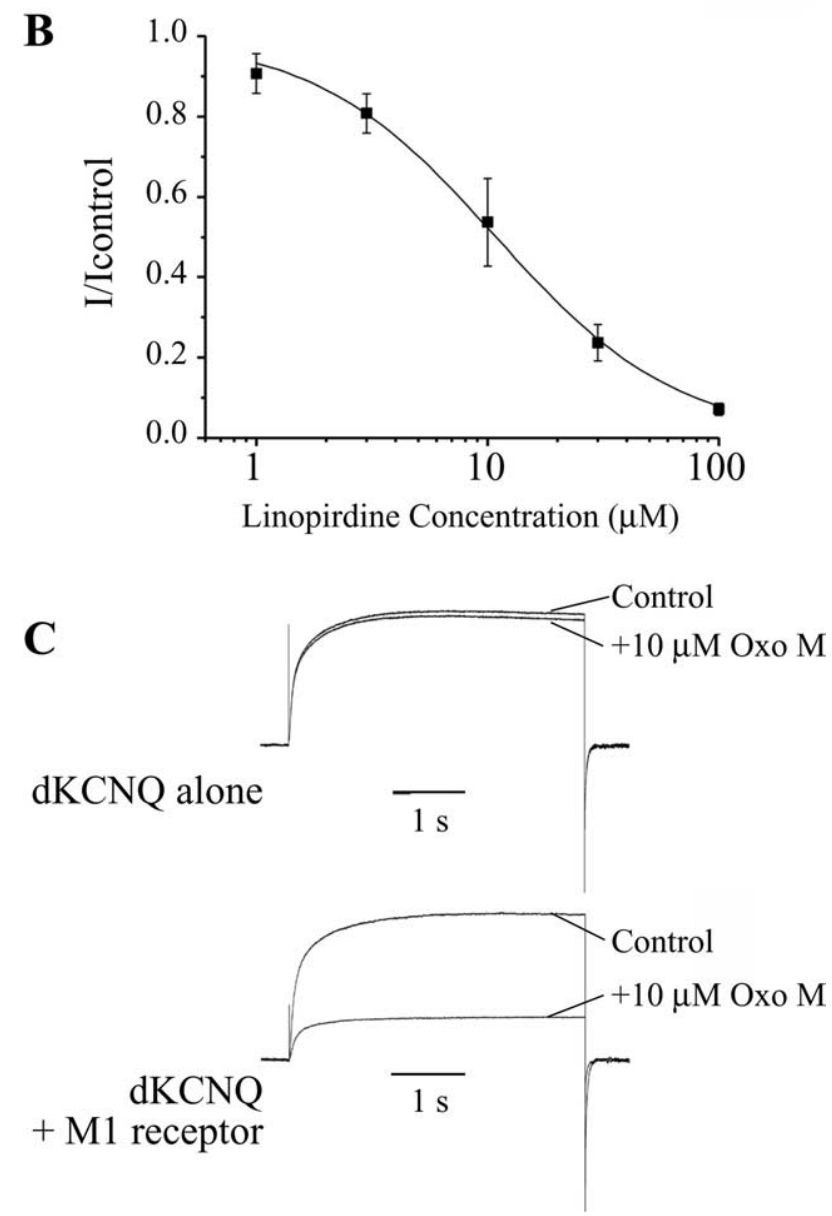

Figure 2. $d K C N Q$ current is blocked by linopirdine and inhibited by the activation of $M_{1}$ receptors. $A$, Representative traces from the same cell before (control) and $2 \mathrm{~min}$ after application of $100 \mathrm{~mm}$ linopirdine. Cells were held at $-80 \mathrm{mV}$, and membrane potential was stepped to $+20 \mathrm{mV}$ in $20 \mathrm{mV}$ increments for $4 \mathrm{~s}$ before being stepped back to $-120 \mathrm{mV}$. Linopirdine was added from a stock solution to the bath to give the final concentration desired. $\boldsymbol{B}$, Linopirdine dose-response curve. Currents were measured in the same cell at $+20 \mathrm{mV}$ before $\left(I_{\text {control }}\right)$ and 2 min after $(/)$ the application of the indicated concentrations of linopirdine. Data were fit to the equation $y=1 /\left(1+\left(x / \mid C_{50}\right)^{h}\right)$, where $\mid C_{50}$ is the dose at which half-maximal block of current is reached, and $h$ is the Hill slope of the curve. The $\mathrm{IC}_{50}$ was found to be $10.8 \mu \mathrm{m}$, and the Hill slope was 1.1. $n \geq 4$ for each data point. C, Comparison of effects of $10 \mu \mathrm{m}$ Oxo M on dKCNQ currents in $\mathrm{CHO}$ cells transfected with the channel alone (top traces) or cotransfected with the channel and mouse $\mathrm{M}_{1}$ receptor (bottom traces). 0 xo $\mathrm{M}$ was added from a stock solution to the bath to give a final concentration of $10 \mu \mathrm{m}$. Whole-cell currents were recorded with a voltage protocol stepping from -80 to $0 \mathrm{mV}$ for $4 \mathrm{~s}$, followed by a step back to $-120 \mathrm{mV}$. Current traces before (control) and 1-2 min after ( $+10 \mu \mathrm{m} 0 \times \mathrm{xo}$ M) 0xo M application are shown. The top and bottom control current traces are normalized for ease of comparison.

KCNQ3 (Wen and Levitan, 2002). When a similar arginine residue is mutated in the dKCNQ channel (R326E), CaM no longer coimmunoprecipitates with the channel protein (Fig. 3A, lane 4). This mutant dKCNQ (R326E) channel produces small currents
A
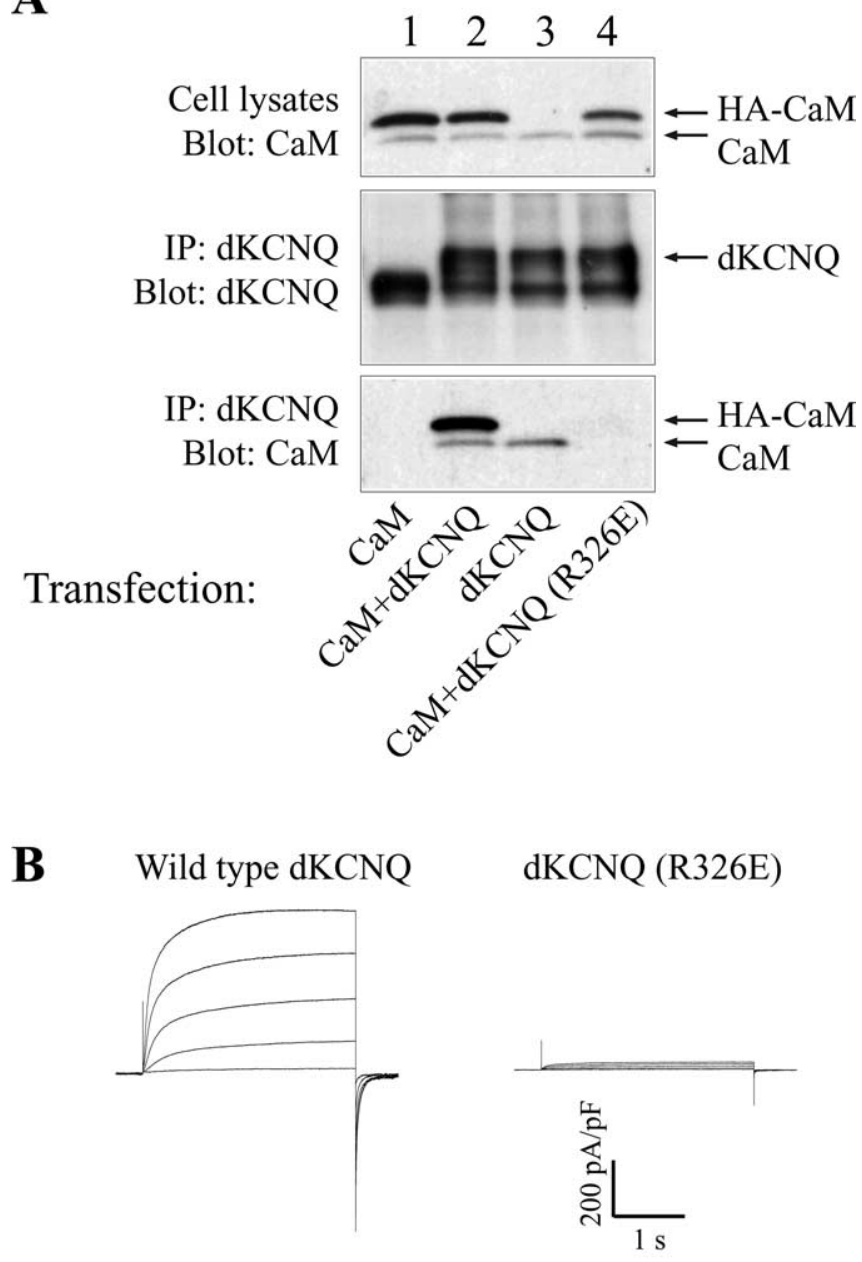

Figure 3. CaM binds to dKCNQ, and CaM binding is necessary for dKCNQ function. $A$, CaM coimmunoprecipitates with wild-type dKCNQ but not a mutant dKCNQ (R326E). tsA201 cells were transfected with CaM alone (lane 1), dKCNQ alone (lane 3), CaM together with wild-type dKCNQ (lane 2), or CaM together with dKCNQ (R326E) (lane 4). Constructs used for transfection were HA-tagged CaM and channel CDNAs in the pIRES2-EGFP expression vector. dKCNQ was precipitated with a polyclonal antibody specific for the channel, J-67 (middle). CaM in the cell lysates (top) and the channel immunoprecipitates (IP; bottom) were detected with a monoclonal anti-CaM antibody. Endogenous CaM is present in the immunoprecipitates of the wild-type channel (bottom, lanes 2 and 3 ), whereas overexpressed HA-tagged CaM also comes down with the channel in the immunoprecipitates from cotransfected cells (bottom, lane 2). Neither endogenous nor overexpressed CaM was observed in the immunoprecipitate of the mutant channel (bottom, lane 4). B, Typical recordings from CHO cells transfected with wild-type (left) and R326E mutant (right) dKCNQ. Whole-cell currents were measured after a similar voltage protocol as in Figure 1 with $20 \mathrm{mV}$ increment steps up to $+20 \mathrm{mV}$. dKCNQ (R326E) has only small residual currents with much slower kinetics.

in some transfected $\mathrm{CHO}$ cells (Fig. 3B). The average current density in cells expressing dKCNQ (R326E) is $16.4 \pm 6.2 \mathrm{pA} / \mathrm{pF}$ $(n=13)$, which is only $7 \%$ of that in cells expressing wild-type dKCNQ $(234.8 \pm 43.5 \mathrm{pA} / \mathrm{pF} ; n=9 ; p<0.05$, Student's $t$ test $)$. The small remaining current could be attributable to some residual binding of CaM to the mutant channel, because we observed a weak signal above background for CaM in the mutant channel immunoprecipitates after long exposure of the blots (20 min to 1 h; data not shown).

Together, our data show that dKCNQ is a functional KCNQ channel. Although the fly equivalent of the mammalian neuronal $\mathrm{M}$-current has not been described, dKCNQ could be a component of a similar current in vivo. We next studied the physiolog- 
ical role of dKCNQ in vivo by examining animals with deletions in $d K C N Q$ genomic DNA.

\section{Generation of $d K C N Q$ deletion lines}

We identified a P-element line, EP(2)2074, in the BDGP database, in which a $\mathrm{P}$-element is inserted $191 \mathrm{bp}$ downstream of the seventh exon of $d K C N Q$ (Fig. 4). To generate deletions in the $d K C N Q$ gene, we used a strategy that takes advantage of the high frequency of imprecise excisions during mobilization of P-elements. EP(2)2074 was remobilized with a stable source of transposase, $\Delta 2-3$, and 103 independent excision lines (referred to as $\mathrm{EP}_{\text {loss }}$ ) were selected. Using a PCR screening method, we recovered five homozygous viable lines that contain deletions of various lengths in the first half of the $d K C N Q$ gene (referred to as $d K C N Q$ deletion lines). Sequencing across the breakpoints of the deletions showed that these lines can be divided into two groups based on the location of the lesions in the transcripts. The first group, including $d K C N Q^{18 B}$, $d K C N Q^{35 B}, d K C N Q^{53 B}$, and $d K C N Q^{64 B}$, lacks the sequence coding for part or all of the S1-S6 transmembrane domains and the conserved CaM-binding site 1 right after S6 (Table 1, Fig. 4). Because they lack the membrane-spanning domains that are essential for potassium channel function, these four lines are functional null alleles for the channel activity of dKCNQ. The second group consists of one line, $d K C N Q^{42 B}$, in which the deletion removes part of exon 8 (Table 1, Fig. 4). RT-PCR experiments revealed three $d K C N Q$ transcripts in these flies arising from alternative splicing (data not shown). Because all three transcripts retain part of the intronic sequences between exon 7 and exon 8 , premature stop codons are introduced several residues downstream of S353 (4 and 22 residues, respectively). Hence, $d K C N Q^{42 B}$ is an allele expressing a mutant $\mathrm{dKCNQ}$, with a C-terminal tail truncated after the conserved CaM-binding site 1. It remains to be tested whether this shortened protein lacking CaM-binding site 2 still has channel activity. We favor the idea that $d K C N Q^{42 B}$ is also a functional null allele, because our previous study of CaM interaction with the mammalian channels suggests that both CaM-binding sites are necessary for CaM binding and that $\mathrm{CaM}$ binding is essential for channel function (Wen and Levitan, 2002).

We also recovered several lines with precise excision of $E P(2) 2074$. DNA sequencing across the original P-element insertion site in one of them, $d K C N Q^{24 B}$, confirmed that the $d K C N Q$ locus in this fly is identical to that of wild-type flies. We then used $d K C N Q^{24 B}$ as the wild-type control for all the experiments described below.

\section{$d K C N Q$ deletion flies have a maternal effect phenotype}

Homozygous $d K C N Q$ deletion flies develop to adulthood, with a viability close to those of $d K C N Q^{24 B}$ and $E P(2) 2074$. Homozygous $d K C N Q$ deletion adults exhibit an $\sim 50: 50$ male to female ratio and have no gross anatomical abnormalities; they also exhibit no obvious defects in such basic motor skills as walking and flying. Mutations in other potassium channels have been shown to cause several characteristic behavioral phenotypes, including ether-induced leg shaking (Kaplan and Trout, 1969; Elkins et al., 1986) and temperature-sensitive paralysis (Elkins et al., 1986;
Table 1. dKCNQ deletion fly lines

\begin{tabular}{llll}
\hline Fly line & Deletion in genomic DNA & Deletion in CDNA & Predicted deletion in protein \\
\hline $24 B$ & None & None & None \\
$18 B$ & +110 to +2053 & Exon $2-7$ & S1-S6 + site 1 \\
$35 B$ & -553 to +3368 & Exon $1-7$ & S1 - S6 + site 1 \\
$42 B$ & +2062 to +3840 & Part of exon 8 & C-terminal sequences after site 1 \\
$53 B$ & +1071 to +3303 & Exon $5-7$ & S5-S6 + site 1 \\
$64 B$ & +453 to +3493 & Exon 3-7 & Part of S1, S2-S6, + site 1 \\
\hline
\end{tabular}

The first nucleotide of the ATG start codon for dKCNQ protein is numbered as + 1. Compared with precise excision line $24 B$, some deletion lines have short $P$-element sequences left between the breakpoints of excision. In line 53B, there is 1 bp (A); in 42B, there are 33 bp (CGTCTTACTTATTTACTTACTTATTTCATCATG); in 18B, there are 22 bp (CATGATGAAATAACAGAATAAC); and in 64B, there are $4 \mathrm{bp}$ (GTTA).

Hegde et al., 1999). In contrast to Shaker, Slo, Shab, and EAG mutants, homozygous $d K C N Q$ deletion flies are indistinguishable from the wild type in these behavioral tests (data not shown), suggesting that dKCNQ serves a different set of physiological functions than these other potassium channels. Interestingly, the deletion flies do appear to have a "restless" phenotype, in that they appear more active than wild-type or $d K C N Q^{24 B}$ controls. We are currently investigating whether there may be a sleep phenotype associated with the $d K C N Q$ gene, and our preliminary studies have shown that deletion flies do appear to exhibit a sleep defect when compared with controls.

In our attempt to establish a homozygous $d K C N Q$ deletion stock by crossing homozygous males and females, we observed that the eggs laid by homozygous mothers failed to hatch into larvae (Table 2, Crosses 1 and 2). We found that this embryonic lethality was associated only with homozygous $d K C N Q$ deletion mothers. The homozygous $d K C N Q$ deletion males have normal fertility, because they can produce adult progeny when mated to wild-type females (Table 2, Cross 3 ). Therefore, the lethality phenotype suggests a maternal effect of dKCNQ products in embryonic development: dKCNQ is essential for early development, and $\mathrm{dKCNQ}$ mRNA or protein is provided maternally to the embryo. The seemingly normal viability of homozygous $d K C N Q$ deletion adult flies, conversely, indicates that zygotic transcription of $d K C N Q$ is not required for development of the animal. This explains why homozygous $d K C N Q$ deletion embryos produced by heterozygous mothers (which can still make a maternal contribution of $d K C N Q$ ) can develop to adulthood. Heterozygous embryos from homozygous $d K C N Q$ deletion females and wild-type males still fail to hatch (Table 2, Cross 2), even with a 
Table 2. Maternal effect of dKCNQ

\begin{tabular}{|c|c|c|c|c|c|}
\hline \multirow[b]{2}{*}{ Fly line } & \multicolumn{2}{|l|}{ Cross 1} & \multicolumn{2}{|l|}{ Cross 2} & Cross 3 \\
\hline & $\begin{array}{l}\text { Female } \\
\Delta / \Delta\end{array}$ & $\begin{array}{l}\text { Male } \\
\Delta / \Delta\end{array}$ & $\begin{array}{l}\text { Female } \\
\Delta / \Delta\end{array}$ & $\begin{array}{l}\text { Male } \\
\text { Sp/Cy0 }\end{array}$ & $\begin{array}{l}\text { Female } \\
\text { Sp/CyO }\end{array}$ \\
\hline $24 B$ & + & & + & & + \\
\hline $18 B$ & - & & - & & + \\
\hline $35 B$ & - & & - & & + \\
\hline $42 B$ & - & & - & & + \\
\hline $53 B$ & - & & - & & + \\
\hline $64 B$ & - & & - & & + \\
\hline
\end{tabular}

The $d K C N Q$ locus on the second chromosome is represented as $\Delta$. The precise excision line $24 B$ was used as control. $S p / C y 0$ was used as the wild-type background. Sp (Sternopleural) is a bristle marker gene located on the second chromosome, and CyO (Curly of Oster) is a second chromosome balancer. + Adult progeny were produced from the cross; - , embryos failed to hatch. All deletion lines gave the same results.
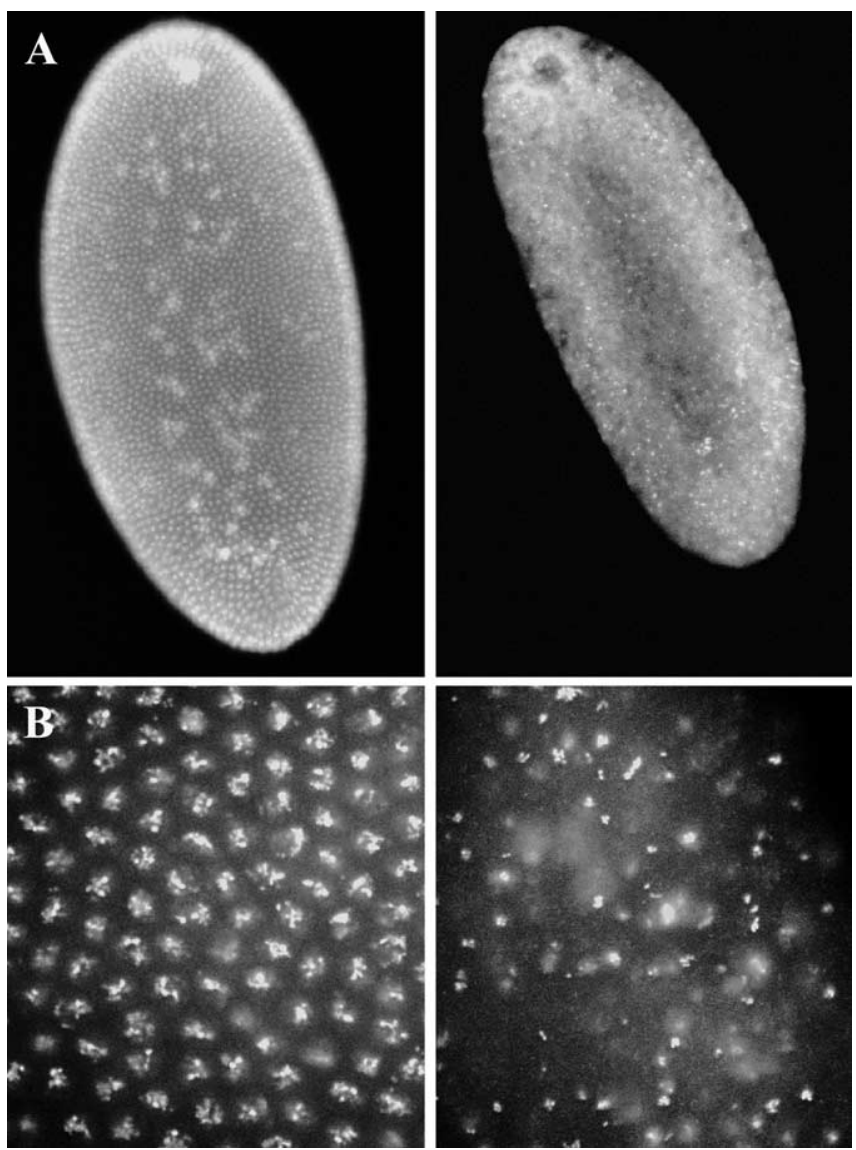

Figure 5. Embryo staining with DAPI. $\boldsymbol{A}$, Nuclear distribution in mid-cleavage stage $d K C N Q^{24 B}$ precise excision (left) and $d K C N Q^{53 B}$ deletion (right) embryos. $\boldsymbol{B}$, Nuclear staining of the embryos in $\boldsymbol{A}$, under higher magnification. In contrast to the wild type (left), the $d K C N Q^{53 B}$ embryo (right) has a disorganized pattern of nuclei on the surface.

copy of the wild-type gene from the male. The lack of paternal rescue indicates that the time window when $d K C N Q$ is critical lies before the zygotic expression of the gene.

We examined embryos produced by homozygous deletion females to further characterize the embryonic lethality phenotype. Using the DNA binding dye DAPI, we looked at the distribution of nuclei in these embryos 1-2 h after egg laying. The mutant embryos show clear nuclear staining (Fig. 5, right panels), suggesting that they have undergone multiple cycles of nuclear division and at least some of the nuclei have migrated to the surface of the embryo. However, the nuclei of the mutant embryos are not organized as in the wild-type embryos (Fig. 5, left panels). In contrast to the orderly packed nuclei seen in the wild type, in the mutants, some nuclei appear to have broken down into smaller fragments whereas others have clustered abnormally, indicating that development of the mutant embryo is arrested before the cellularization stage.

We ascribe this maternal effect phenotype solely to deletions in the $d K C N Q$ gene, because the genomic sequences of genes upstream and downstream of $d K C N Q$ were not affected in the deletion lines (Fig. 4). Because all five independently generated deletion lines display this phenotype although the precise jump-out does not, it is highly unlikely that the phenotype is attributable to some second-site mutation.

\section{dKCNQ mRNA distribution}

Because of the intriguing developmental phenotype seen in the offspring of homozygous deletion females, we asked whether $d K C N Q$ mRNA is found in embryos. We collected embryos within $1 \mathrm{~h}$ of laying to ensure that zygotic transcription had not yet begun. RT-PCR reveals $d K C N Q$ mRNA in early embryos from $d K C N Q^{24 B}$, Canton $S$, and yellow white females (data not shown) but not in the embryos from $d K C N Q^{53 B}$ deletion females crossed with $d K C N Q^{53 B}$ males (Fig. 6) or $d K C N Q^{24 B}$ males (data not shown). To determine whether $d K C N Q$ mRNA is also found in the ovary, we performed whole adult fly and whole ovary in situ hybridization. $d K C N Q$ mRNA is present in brain cortical neurons (Fig. 7A, long arrows), optic lobe lamina (short arrows) and photoreceptors (arrowheads), and the cardia (proventriculus) of the thorax (data not shown). In addition, the nurse cells of the ovaries (Fig. $7 C, D$, arrow), as well as the maturing oocytes (Fig. $7 C$, arrowhead), contain high levels of $d K C N Q$ mRNA. No message was noted in male reproductive tracts (data not shown) nor in brain or ovary of $d K C N Q^{53 B}$ deletion lines (Fig. $7 B, E$ ). These data, combined with the embryo RT-PCR results and the fact that the offspring of $d K C N Q$ deletion females do not develop into adults, support the idea that $d K C N Q$ is a maternally contributed gene and is essential for early embryonic development.

\section{Discussion}

\section{Cloning and electrophysiological analysis of dKCNQ}

We cloned from Drosophila a single KCNQ-related gene, $d K C N Q$, based on its sequence homology to mammalian KCNQ channels. The cloned channel produces a KCNQ-like current in $\mathrm{CHO}$ cells with subthreshold voltage activation and slow kinetics. This current is sensitive to the M-current selective blocker linopirdine and is modulated by activation of a muscarinic receptor. Like KCNQ2, the fly channel binds CaM and requires CaM binding for its functional expression. Therefore, dKCNQ exhibits many characteristics of the mammalian channels. Especially interesting is the modulation of dKCNQ by activation of a muscarinic receptor, the defining feature of the $\mathrm{M}$-current. It is important to point out that, although cDNA for a mammalian $M_{1}$ receptor was used in this study, activation of the Drosophila muscarinic receptor leads to apparently similar downstream signaling events, including stimulation of phosphatidylinositol metabolism (Shapiro et al., 1989; Chyb et al., 1999). Therefore, muscarinic modulation of the $\mathrm{dKCNQ}$ channel could occur in the fly, but its physiological significance is yet to be identified. It also remains to be determined whether other modulators of the mammalian M-current can modulate $\mathrm{dKCNQ}$. 


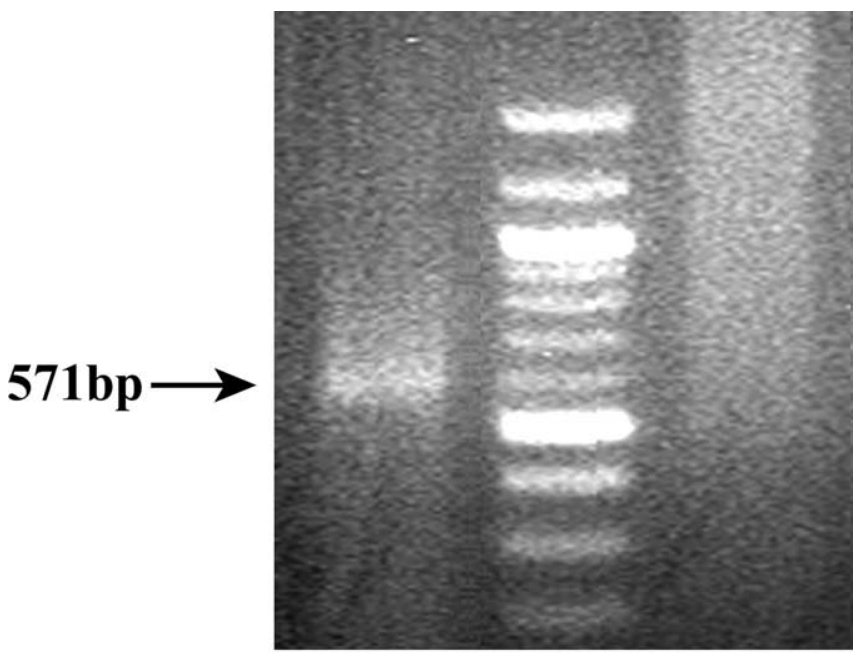

24Bx24B L 53Bx53B

Figure 6. RT-PCR of $d K C N Q^{24 B}$ and $d K C N Q^{53 B}$ early embryos. mRNA for $d K C N Q$ is seen in embryos from $d K C N Q^{24 B}$ females crossed with $d K C N Q^{24 B}$ males (left lane, arrow). In $d K C N Q^{53 B}$ females crossed with $d K C N Q^{53 B}$ males, no message is found (right lane). Predicted band size, 571 bp. L, Ladder.

$d K C N Q$ is the only gene in the Drosophila genome that has significant homology with mammalian KCNQ channels. The five $K C N Q$ genes that have been identified in mammals have overlapping expression patterns in the nervous system and other tissues. They contribute to several distinct native potassium currents of great physiological importance. It will be interesting to see whether a single Drosophila gene can fulfill the functions of these multiple mammalian genes. Mammalian KCNQs can associate with other $\alpha$-subunits within the family, or $\beta$-subunits, to form heteromeric channels that have distinct functional properties. For instance, two $\beta$-subunits with a single membrane-spanning domain, KCNE1 and KCNE3, have profound effects on KCNQ1 channel properties (Sanguinetti et al., 1996; Schroeder et al., 2000b). Although homology search reveals no KCNE-related $\beta$-subunit in the Drosophila genome (Littleton and Ganetzky, 2000), dKCNQ could use some as yet unidentified protein as its auxiliary subunit. We detected at least three alternativespliced transcripts in RT-PCR products from wild-type flies (data not shown). It hence seems likely that isoforms of dKCNQ channels exist in vivo, and functional diversity from a single $d K C N Q$ gene is plausible.

\section{A developmental role for $\mathrm{dKCNQ}$}

Because multiple KCNQ subunits exist in mammals, and they express in overlapping areas and often interact with each other to form heteromeric channels, mutations in one subunit may not produce easily detectable phenotypes attributable to functional compensation by other subunits. Indeed, most patients with mutated forms of KCNQ2 or KCNQ3 have seizures only during the first few weeks after birth and then become apparently normal, except for a slightly higher susceptibility to seizures later in life (Ronen et al., 1993; Psenka and Holden, 1996). Because $d K C N Q$ is the only KCNQ-like gene in Drosophila, a $d K C N Q$ mutant can provide fundamental insight into the requirement of KCNQ-like channels in processes as diverse as differentiation, development, synaptic plasticity, and regulation of neuronal excitability.

Indeed, we observed an unexpected embryonic lethal phenotype in $d K C N Q$ deletion flies. Our results show that embryos produced by homozygous deletion females fail to survive, strongly suggesting that $\mathrm{KKCNQ}$ protein or mRNA is required in early developmental events and is provided maternally to the embryo. The fact that $d K C N Q$ mRNA is found in the ovary and in the early embryo (before zygotic transcription) further supports this hypothesis. Even more intriguingly, homozygous $d K C N Q$ deletion embryos produced by heterozygous females can develop into healthy adults. Thus, beyond the lifetime of the maternally contributed products, dKCNQ can be completely absent without destructive consequences on the development of the animal. This observation supports the idea that maternally deposited $d K C N Q$ is sufficient to sustain the development of the embryo, and $\mathrm{zy}$ gotic expression of the $d K C N Q$ gene is dispensable. This could be attributable to compensation of dKCNQ function by other $\mathrm{Kv}$ channels in later developmental stages.

As illustrated by the nuclear staining, the orderly nuclear distribution characteristic of a mid- to late-cleavage stage wild-type embryo is disrupted in embryos without dKCNQ products, suggesting that these mutant embryos die before cell formation (cell formation in the fly embryo starts $\sim 2.5 \mathrm{~h}$ after egg laying). It is not clear whether Drosophila expresses potassium currents at such an early stage of development. The first currents that can be
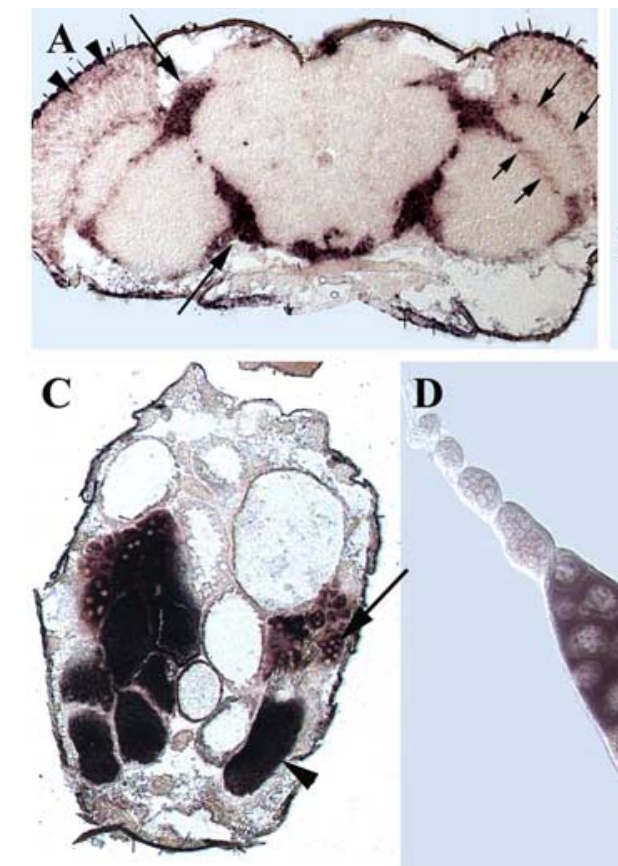

D
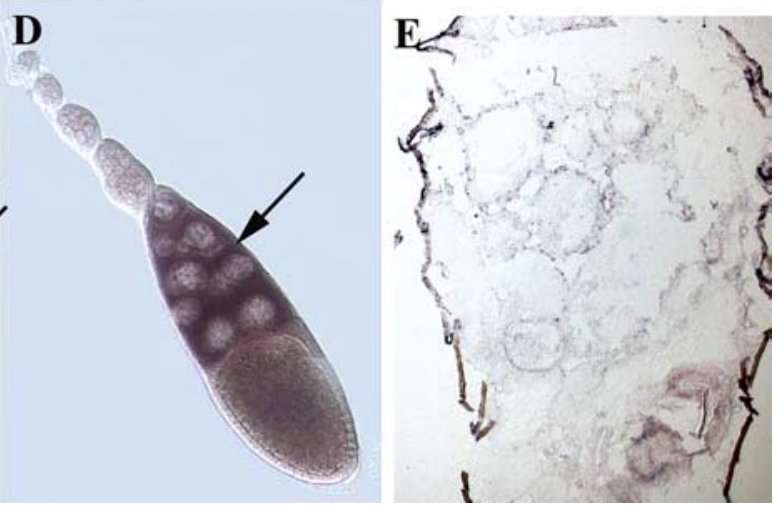

Figure 7. Distribution of $d K C N Q m R N A$ in the adult fly. $A$, In $d K C N Q^{24 B}$ flies, staining is seen in the brain cortex (long arrows) and optic lobe lamina (short arrows), as well as in the photoreceptor layer of the eyes (arrowheads). $\boldsymbol{B}$, In $d K C N Q^{53 B}$ homozygous deletion flies, no staining is noted within the brain. $C$, In a cross-section of a $d K C N Q^{24 B}$ female abdomen, $m R N A$ is noted in the nurse cell region of the egg chamber (arrow), as well as within developing oocytes (arrowhead). $\boldsymbol{D}$, In a single ovariole, dKCNQ mRNA is present in the nurse cell region of a developing oocyte. $\boldsymbol{E}$, No staining is observed in the abdomen of $d K C N Q^{53 B}$ deletion females. All tissue sections were processed at the same time and treated identically. 
recorded from Drosophila embryonic central neurons include a delayed potassium current that appears during midembryogenesis (13-14 h after egg laying) (Baines and Bate, 1998). Does the essential role of dKCNQ for early embryonic development require its channel activity? Ionic flow and resting membrane potential have been implicated in the regulation of embryonic morphogenesis, best studied in chick and Xenopus (Rutenberg et al., 2002). Consistent with this idea, several ion channel and ion pump mRNAs are present in specific and dynamic expression patterns in early embryos in both species, well before neuralization. These include maternal KCNQ1 mRNA, which is present in unfertilized embryos and in cells at earlycleavage stages in chick (Rutenberg et al., 2002). It is conceivable that ionic currents and membrane potential could also play important roles in early embryonic development in the fly. Sustained potassium current at subthreshold membrane potentials produced by mammalian KCNQ channels has been shown to be a key regulator of resting potential (Brown and $\mathrm{Yu}, 2000$; Oliver et al., 2003). Alternatively, dKCNQ could serve some critical function other than as an ion channel protein. For example, dKCNQ may be a component of a signaling complex that transduces external cues into cellular responses in the developing embryo. As a membrane protein with a long cytoplasmic tail containing signaling protein binding sites, $\mathrm{dKCNQ}$ is well suited for such a role.

\section{References}

Adams MD, Celniker SE, Holt RA, Evans CA, Gocayne JD, Amanatides PG, Scherer SE, Li PW, Hoskins RA, Galle RF, George RA, Lewis SE, Richards S, Ashburner M, Henderson SN, Sutton GG, Wortman JR, Yandell MD, Zhang Q, Chen LX, et al. (2000) The genome sequence of Drosophila melanogaster. Science 287:2185-2195.

Adelman JP, Shen KZ, Kavanaugh MP, Warren RA, Wu YN, Lagrutta A, Bond CT, North RA (1992) Calcium-activated potassium channels expressed from cloned complementary DNAs. Neuron 9:209-216.

Atkinson NS, Robertson GA, Ganetzky B (1991) A component of calciumactivated potassium channels encoded by the Drosophila slo locus. Science 253:551-555.

Baines RA, Bate M (1998) Electrophysiological development of central neurons in the Drosophila embryo. J Neurosci 18:4673-4683.

Biervert C, Schroeder BC, Kubisch C, Berkovic SF, Propping P, Jentsch TJ, Steinlein OK (1998) A potassium channel mutation in neonatal human epilepsy. Science 279:403-406.

Brown BS, Yu SP (2000) Modulation and genetic identification of the M channel. Prog Biophys Mol Biol 73:135-166.

Brown DA, Adams PR (1980) Muscarinic suppression of a novel voltagesensitive $\mathrm{K}^{+}$current in a vertebrate neurone. Nature 283:673-676.

Charlier C, Singh NA, Ryan SG, Lewis TB, Reus BE, Leach RJ, Leppert M (1998) A pore mutation in a novel KQT-like potassium channel gene in an idiopathic epilepsy family. Nat Genet 18:53-55.

Chyb S, Raghu P, Hardie RC (1999) Polyunsaturated fatty acids activate the Drosophila light-sensitive channels TRP and TRPL. Nature 397:255-259.

Costa AM, Brown BS (1997) Inhibition of M-current in cultured rat superior cervical ganglia by linopirdine: mechanism of action studies. Neuropharmacology 36:1747-1753.

Elkins T, Ganetzky B, Wu CF (1986) A Drosophila mutation that eliminates a calcium-dependent potassium current. Proc Natl Acad Sci USA 83:8415-8419.

Gamper N, Shapiro MS (2003) Calmodulin mediates $\mathrm{Ca}^{2+}$-dependent modulation of M-type $\mathrm{K}^{+}$channels. J Gen Physiol 122:17-31.

Hegde P, Gu GG, Chen D, Free SJ, Singh S (1999) Mutational analysis of the Shab-encoded delayed rectifier $\mathrm{K}^{+}$channels in Drosophila. J Biol Chem 274:22109-22113.

Hille B (2001) Ionic channels of excitable membranes. Sunderland, MA: Sinauer.

Jensen HS, Callo K, Jespersen T, Jensen BS, Olesen SP (2005) The KCNQ5 potassium channel from mouse: a broadly expressed M-current like potassium channel modulated by zinc, $\mathrm{pH}$, and volume changes. Brain Res Mol Brain Res 139:52-62.

Kamb A, Iverson LE, Tanouye MA (1987) Molecular characterization of
Shaker, a Drosophila gene that encodes a potassium channel. Cell 50:405-413.

Kaplan WD, Trout WE (1969) The behavior of four neurological mutants of Drosophila. Genetics 61:399-409.

Kubisch C, Schroeder BC, Friedrich T, Lutjohann B, El Amraoui A, Marlin S, Petit C, Jentsch TJ (1999) KCNQ4, a novel potassium channel expressed in sensory outer hair cells, is mutated in dominant deafness. Cell 96:437-446.

Lamas JA, Selyanko AA, Brown DA (1997) Effects of a cognition-enhancer, linopirdine (DuP 996), on M-type potassium currents (IK(M)) and some other voltage- and ligand-gated membrane currents in rat sympathetic neurons. Eur J Neurosci 9:605-616.

Lerche C, Scherer CR, Seebohm G, Derst C, Wei AD, Busch AE, Steinmeyer K (2000) Molecular cloning and functional expression of KCNQ5, a potassium channel subunit that may contribute to neuronal M-current diversity. J Biol Chem 275:22395-22400.

Littleton JT, Ganetzky B (2000) Ion channels and synaptic organization: analysis of the Drosophila genome. Neuron 26:35-43.

Neyroud N, Tesson F, Denjoy I, Leibovici M, Donger C, Barhanin J, Faure S, Gary F, Coumel P, Petit C, Schwartz K, Guicheney P (1997) A novel mutation in the potassium channel gene KvLQT1 causes the Jervell and Lange-Nielsen cardioauditory syndrome. Nat Genet 15:186-189.

O’Kane CJ (1998) Enhancer trap. In: Drosophila: a practical approach (Roberts DB, ed), pp 131-175. New York: Oxford UP.

Oliver D, Knipper M, Derst C, Fakler B (2003) Resting potential and submembrane calcium concentration of inner hair cells in the isolated mouse cochlea are set by KCNQ-type potassium channels. J Neurosci 23:2141-2149.

Papazian DM, Schwarz TL, Tempel BL, Jan YN, Jan LY (1987) Cloning of genomic and complementary DNA from Shaker, a putative potassium channel gene from Drosophila. Science 237:749-753.

Pongs O, Kecskemethy N, Muller R, Krah-Jentgens I, Baumann A, Kiltz HH, Canal I, Llamazares S, Ferrus A (1988) Shaker encodes a family of putative potassium channel proteins in the nervous system of Drosophila. EMBO J 7:1087-1096.

Psenka TM, Holden KR (1996) Benign familial neonatal convulsions; psychosocial adjustment to the threat of recurrent seizures. Seizure 5:243-245.

Robertson HM, Preston CR, Phillis RW, Johnson-Schlitz DM, Benz WK, Engels WR (1988) A stable genomic source of P element transposase in Drosophila melanogaster. Genetics 118:461-470.

Ronen GM, Rosales TO, Connolly M, Anderson VE, Leppert M (1993) Seizure characteristics in chromosome 20 benign familial neonatal convulsions. Neurology 43:1355-1360.

Rorth P (1996) A modular misexpression screen in Drosophila detecting tissue-specific phenotypes. Proc Natl Acad Sci USA 93:12418-12422.

Rorth P, Szabo K, Bailey A, Laverty T, Rehm J, Rubin GM, Weigmann K, Milan M, Benes V, Ansorge W, Cohen SM (1998) Systematic gain-offunction genetics in Drosophila. Development 125:1049-1057.

Rutenberg J, Cheng SM, Levin M (2002) Early embryonic expression of ion channels and pumps in chick and Xenopus development. Dev Dyn 225:469-484

Sanguinetti MC, Curran ME, Zou A, Shen J, Spector PS, Atkinson DL, Keating MT (1996) Coassembly of KvLQT1 and IsK (minK) proteins to form cardiac IKs potassium channel. Nature 384:80-83.

Schroeder BC, Kubisch C, Stein V, Jentsch TJ (1998) Moderate loss of function of cyclic-AMP-modulated KCNQ2/KCNQ3 $\mathrm{K}^{+}$channels causes epilepsy. Nature 396:687-690.

Schroeder BC, Hechenberger M, Weinreich F, Kubisch C, Jentsch TJ (2000a) KCNQ5, a novel potassium channel broadly expressed in brain, mediates M-type currents. J Biol Chem 275:24089-24095.

Schroeder BC, Waldegger S, Fehr S, Bleich M, Warth R, Greger R, Jentsch TJ (2000b) A constitutively open potassium channel formed by KCNQ1 and KCNE3. Nature 403:196-199.

Schulze-Bahr E, Wang Q, Wedekind H, Haverkamp W, Chen Q, Sun Y, Rubie C, Hordt M, Towbin JA, Borggrefe M, Assmann G, Qu X, Somberg JC, Breithardt G, Oberti C, Funke H (1997) KCNE1 mutations cause jervell and Lange-Nielsen syndrome. Nat Genet 17:267-268.

Selyanko AA, Hadley JK, Wood IC, Abogadie FC, Jentsch TJ, Brown DA (2000) Inhibition of KCNQ1-4 potassium channels expressed in mammalian cells via M1 muscarinic acetylcholine receptors. J Physiol (Lond) 522:349-355. 
Shapiro MS, Roche JP, Kaftan EJ, Cruzblanca H, Mackie K, Hille B (2000) Reconstitution of muscarinic modulation of the KCNQ2/KCNQ3 $\mathrm{K}^{+}$ channels that underlie the neuronal M current. J Neurosci 20:1710-1721.

Shapiro RA, Wakimoto BT, Subers EM, Nathanson NM (1989) Characterization and functional expression in mammalian cells of genomic and cDNA clones encoding a Drosophila muscarinic acetylcholine receptor. Proc Natl Acad Sci USA 86:9039-9043.

Singh NA, Charlier C, Stauffer D, DuPont BR, Leach RJ, Melis R, Ronen GM, Bjerre I, Quattlebaum T, Murphy JV, McHarg ML, Gagnon D, Rosales TO, Peiffer A, Anderson VE, Leppert M (1998) A novel potassium channel gene, KCNQ2, is mutated in an inherited epilepsy of newborns. Nat Genet 18:25-29.

Suh BC, Hille B (2002) Recovery from muscarinic modulation of M current channels requires phosphatidylinositol 4,5-bisphosphate synthesis. Neuron 35:507-520.

Wang HS, Pan Z, Shi W, Brown BS, Wymore RS, Cohen IS, Dixon JE, McKinnon D (1998) KCNQ2 and KCNQ3 potassium channel subunits: molecular correlates of the M-channel. Science 282:1890-1893.

Wang J, Zhou Y, Wen H, Levitan IB (1999) Simultaneous binding of two protein kinases to a calcium-dependent potassium channel. J Neurosci 19:RC4(1-7).

Wang Q, Curran ME, Splawski I, Burn TC, Millholland JM, VanRaay TJ, Shen J, Timothy KW, Vincent GM, de Jager T, Schwartz PJ, Toubin JA, Moss AJ, Atkinson DL, Landes GM, Connors TD, Keating MT (1996) Positional cloning of a novel potassium channel gene: KvLQT1 mutations cause cardiac arrhythmias. Nat Genet 12:17-23.
Warmke J, Drysdale R, Ganetzky B (1991) A distinct potassium channel polypeptide encoded by the Drosophila eag locus. Science 252:1560-1562.

Wei A, Jegla T, Salkoff L (1996) Eight potassium channel families revealed by the C. elegans genome project. Neuropharmacology 35:805-829.

Wei AD, Butler A, Salkoff L (2005) KCNQ-like potassium channels in Caenorhabditis elegans. Conserved properties and modulation. J Biol Chem 280:21337-21345.

Wen H, Levitan IB (2002) Calmodulin is an auxiliary subunit of KCNQ2/3 potassium channels. J Neurosci 22:7991-8001.

Wu CF, Ganetzky B, Haugland FN, Liu AX (1983) Potassium currents in Drosophila: different components affected by mutations of two genes. Science 220:1076-1078.

Yang WP, Levesque PC, Little WA, Conder ML, Shalaby FY, Blanar MA (1997) KvLQT1, a voltage-gated potassium channel responsible for human cardiac arrhythmias. Proc Natl Acad Sci USA 94:4017-4021.

Yu SP, Kerchner GA (1998) Endogenous voltage-gated potassium channels in human embryonic kidney (HEK293) cells. J Neurosci Res 52:612-617.

Yus-Najera E, Santana-Castro I, Villarroel A (2002) The identification and characterization of a noncontinuous calmodulin-binding site in noninactivating voltage-dependent KCNQ potassium channels. J Biol Chem 277:28545-28553.

Zhang H, Craciun LC, Mirshahi T, Rohacs T, Lopes CM, Jin T, Logothetis DE (2003) PIP(2) activates KCNQ channels, and its hydrolysis underlies receptor-mediated inhibition of $M$ currents. Neuron 37:963-975.

Zhong Y, Wu CF (1991) Alteration of four identified $\mathrm{K}^{+}$currents in Drosophila muscle by mutations in eag. Science 252:1562-1564. 